Open Access

\title{
Ethnobotany, Phytochemistry, and Biological Activities of Taxodium Rich.
}

\author{
Zushang Su, Wei Yuan, Ping Wang and Shiyou $\mathrm{Li}^{*}$
}

National Center for Pharmaceutical Crops, Arthur Temple College of Forestry and Agriculture, Stephen F. Austin State University, Nacogdoches, TX 75962-6109, USA

\begin{abstract}
Taxodium Rich. is a genus of the family Cupressaceae. The trees are especially prized for their rot and termite resistant wood. Taxodium leaves and cones, which are particularly rich in essential oils were used as folk medicine to treat skin, gastro-intestinal, respiratory, inflammation, and infections. Preliminary bioactivity assays reported antimicrobial, antitumor, antitermitic, antispasmodic and bronchodilator activities of the extracts or isolates from Taxodium but further pharmacological investigations of bioactive compounds are not available. To data, at least 130 compounds have been identified from extant or fossil Taxodium. Fifty-seven compounds have been isolated primarily from the cones, leaves, and branches of extant Taxodium, with diterpenoids and flavonoids as the major components. At least three major abietane diterpenoids (sugiol (1), ferruginol (2), and 6,7-dehydroferruginol (3)) are also identified in the fossil Taxodium by GC/MS. The diterpenoids may be important marker compounds for understanding the evolution of the genus Taxodium. However, the taxonomy and evolutionary pattern of Taxodium remains elusive until a full understanding of the chemical constituents of all Taxodium taxa is determined.
\end{abstract}

Keywords: Taxodium, baldcypress, pondcypress, montezuma cypress, fossil, essential oils, diterpenoids, flavonoids, biological activities, pharmacological activities.

\section{INTRODUCTION}

Taxodium Rich. is a genus of Cupressaceae with three extant taxa ranging from the eastern United States through Mexico to Guatemala [1]. The trees are especially prized for their wood, of which the heartwood is extremely rot and termite resistant [2]. Taxodium leaves and cones, which are particularly rich in essential oils were used as folk medicine to treat skin, gastro-intestinal, respiratory, inflammation, and infections [3, 4]. In vitro assays support some of the medicinal uses but need to be confirmed by further pharmacological investigations and human clinical trials. It is well known that diterpenoids and flavonoids are the main secondary metabolites of this genus and are responsible for some of the bioactivities. To date, a chemical and pharmacological review of Taxodium is not available. Hence, the present review is an endeavor mainly focusing on the research reports of the ethnobotany, phytochemistry, and biological and pharmacological properties of the genus Taxodium.

\section{ETHNOBOTANICAL USES}

It is generally accepted that there are three taxa in the genus Taxodium. These three taxa were treated as three separate species $T$. distichum (L.) Rich., T. ascendens Brongn., and T. mexicanum Carr. (T. mucronatum Ten. or T. huegelii C. Lawson) [5] as two species, one having two varieties $[6,7]$. But more commonly three varieties are recognized under one polymorphic species $T$. distichum (L.).

*Address correspondence to this author at the National Center for Pharmaceutical Crops, Arthur Temple College of Forestry and Agriculture, Stephen F. Austin State University, Nacogdoches, TX 75962-6109, USA;

Tel: +1 936-468-2071; Fax: +1 936-468-7058; E-mail: lis@sfasu.edu.
Rich.: var distichum, var. imbricarium (Nutt.) Croom., and var. mexicanum (Carr.) Gord. [1, 8, 9]. Earlier DNA analysis using cleaved amplified polymorphic sequences [10] and allozyme analysis [11] support the treatment of varietal status of $T$. ascendens (T. distichum var. imbricarium). Recent DNA sequencing and terpenoid analyses support the recognition of Taxodium Rich. as a monotypic genus with three varieties under $T$. distichum [12]. In this review, we adopt this classification.

Taxodium distichum var. distichum is known as baldcypress and distributed in the eastern United States from Maryland and Illinois south into Florida and Central Texas [13]. Taxodium distichum var. imbricarium, pondcypress, is native to the southeastern United States from Florida and the Gulf Coast east of Texas, and up the Atlantic coast to North Carolina [13]. Taxodium distichum var. mexicanum, Montezuma or Mexican cypress, is distributed in much of Mexico, the southernmost Texas of the United States as well as Huehuetenango Department in Guatemala. Both baldcypress and pondcypress are deciduous while Montezuma cypress is semi-evergreen. Taxodium trees can grow on rivers, lake margins, swamps, wet poorly drained habitats and are tolerant to various soil conditions and air pollution [14]. These fast-growing and long-lived conifers have been widely used for landscape in many countries. The heartwood of baldcypress is used for building materials, and has been reported to resist the attacks of the subterranean termite, Coptotermes formosanus Shiraki [2, 15] (Fig. 1). The cones and seeds of Taxodium tend to be discovered from ancient stratum, and there are several reports of the fossil conifer and sediments of ancient flora $[16,17]$. Montezuma cypress is the national tree of Mexico, and in addition to its historical and cultural 


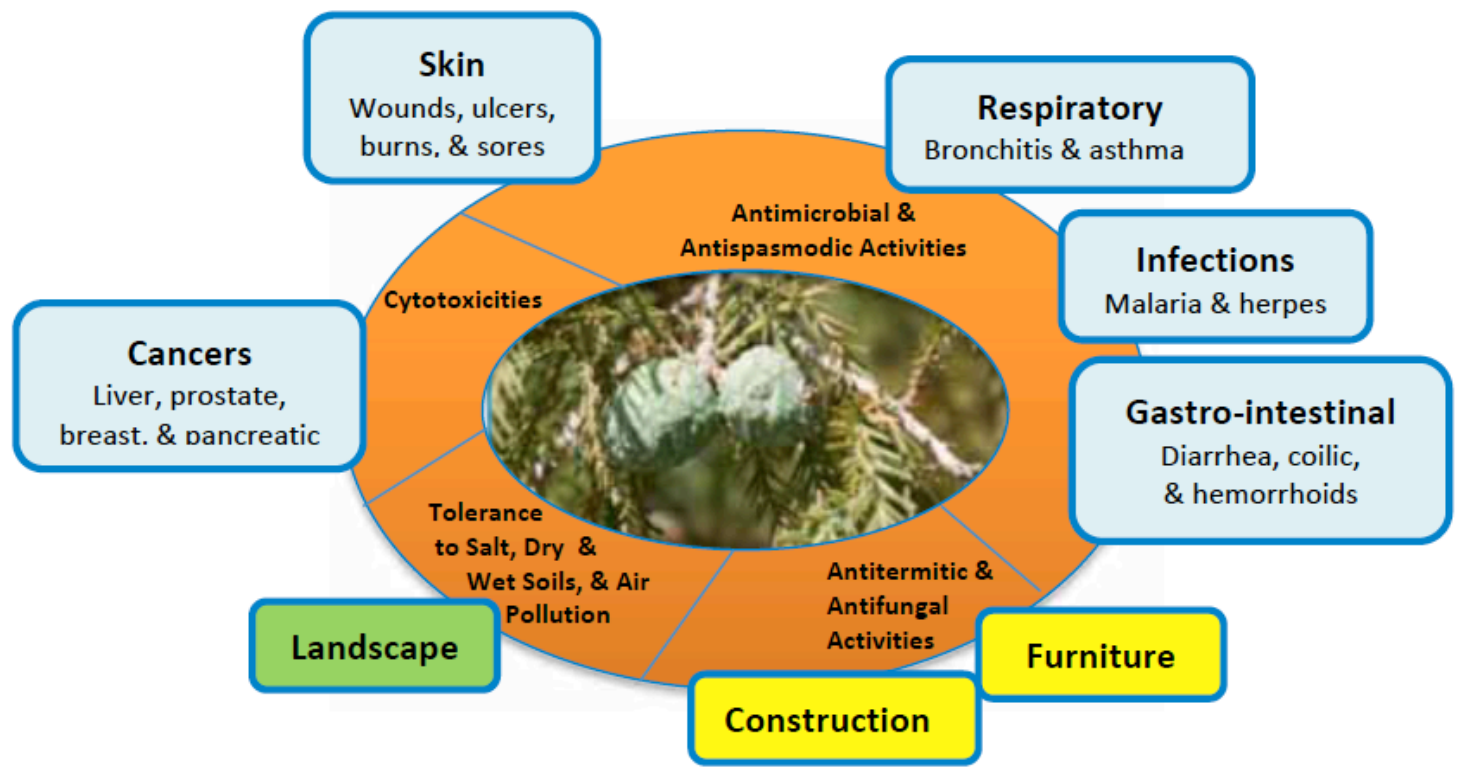

Fig. (1). Bioactivities, ecological features, and uses of Taxodium.

importance, it has great ecological value [18]. These trees reach considerable size and age and they are the largest and oldest species of tree in Mexico [19]. Taxodium had wide distribution throughout North America, Europe, and East Asia during the Cretaceous until the Pleistocene [10]. Several fossil species have been identified, e.g., T. wallissii Aulenback et LePage (late Cretaceous), T. dubium (Sternberg) Heer (early Tertiary), and T. balticum Sveshn. Et Budants (Eocene) $[17,20]$.

The leaves and seeds of Taxodium have been used for treatment of malaria and liver diseases [21]. The seeds of Taxodium have been reported to possess antitumor activities $[22,23]$. Several parts of Montezuma cypress were used by the Aztecs; in particular, the gummy resin that can be obtained from a cut tree or its burned wood was used as a medicine. Pieces of the burned bark were placed directly on sores, burns and ulcerations of the skin. In addition, chest pains could be treated and potentially cured by inhaling the smoke from burning wood and branches. Currently, the bark, branches, leaves and cones of this tree are used to create infusions or ointments for the treatment of wounds, gout, cardiac diseases, hemorrhoids, ulcers and varices, to relieve rheumatic pain, or as antispasmodics for the treatment of diarrhea and bronchial problems [3, 4]. Martínez reported that resinous parts of the leaves and cones may effectively treat herpes and leg tumors and reduce inflammation and rapidly resolve articular diseases [24]. Infusions of the leaves have also been reported as hypoglycemic [25]. The only published pharmacological study on this species detailed a vasorelaxant effect of the aqueous extract from the aerial part of the tree [26]. The recorded treatment effects of the medicinal products derived from the Taxodium taxa have not been further verified by additional pharmacological or controlled clinical studies.

\section{CHEMICAL CONSTITUENTS}

Natural products isolated from plants provide an unparalleled source of chemical diversity for discovery of biologically active molecules. The constituents and functions of Taxodium have been investigated by both isolation-tobioassay and bioassay-guided isolation approaches via various chromatographic techniques including thin layer chromatography (TLC), high performance liquid chromatography (HPLC), ultra performance liquid chromatography (UPLC), gas chromatography (GC), and multidimensional chromatography. Among these techniques, liquid chromatography is used most frequently. This review article covers the reports on 130 compounds isolated or identified from the extant $T$. distichum and the fossil T. balticum and T. dubium: 23 major compounds from essential oils (Table 1) and 107 nonessential oil compounds such as diterpenoids, triterpenoids, steroids, lignins, flavonoids, and other compounds (Table 2). From the cones, seeds, leaves, and branches of the three extant taxa of Taxodium, 57 compounds, including 16 diterpenoids (1-14, 21, and 22), two triterpenoids (26 and 27), two steroids (50 and 51), six lignins (52-57), 25 flavonoids (5882), and six other compounds (102-107) have been isolated and more than 60 compounds have been identified from the essential oils and four aliphatic lipids (91-94) by gas chromatography-mass spectroscopy (GC-MS). 50 compounds have been identified from the fossil T. balticum and $T$. $d u$ bium by GC-MS. Interestingly, four of these compounds including three diterpenoids: sugiol (1), feruginol (2), and 6,7-dehydroferruginol (5) and one steroid $\beta$-sitosterol (50) were also isolated from extant species as major compounds. However, existing data do not provide a complete profile of chemical constituents of Taxodium because chemical investigation is limited on extant or fossil taxa. In Tables $\mathbf{1}$ and $\mathbf{2}$, any taxon lacking data of any compound or class of compounds is not an indication that these compounds or class of compounds in the taxon do not exist. Their absence may be due to the incomplete chemical investigation. Thus, it is premature to make chemical comparisons among any extant taxa, fossil species, or between extant and fossil Taxodium.

\section{Chemical Composition of Essential Oils}

GC is sensitive in detecting volatile chemical compounds or non-volatile compounds readily derivatized. Structural 
Table 1. Comparison of the Major Compounds of the Essential oils of Taxodium distichum var. distichum from Different Regions (by GC/MS Analysis)

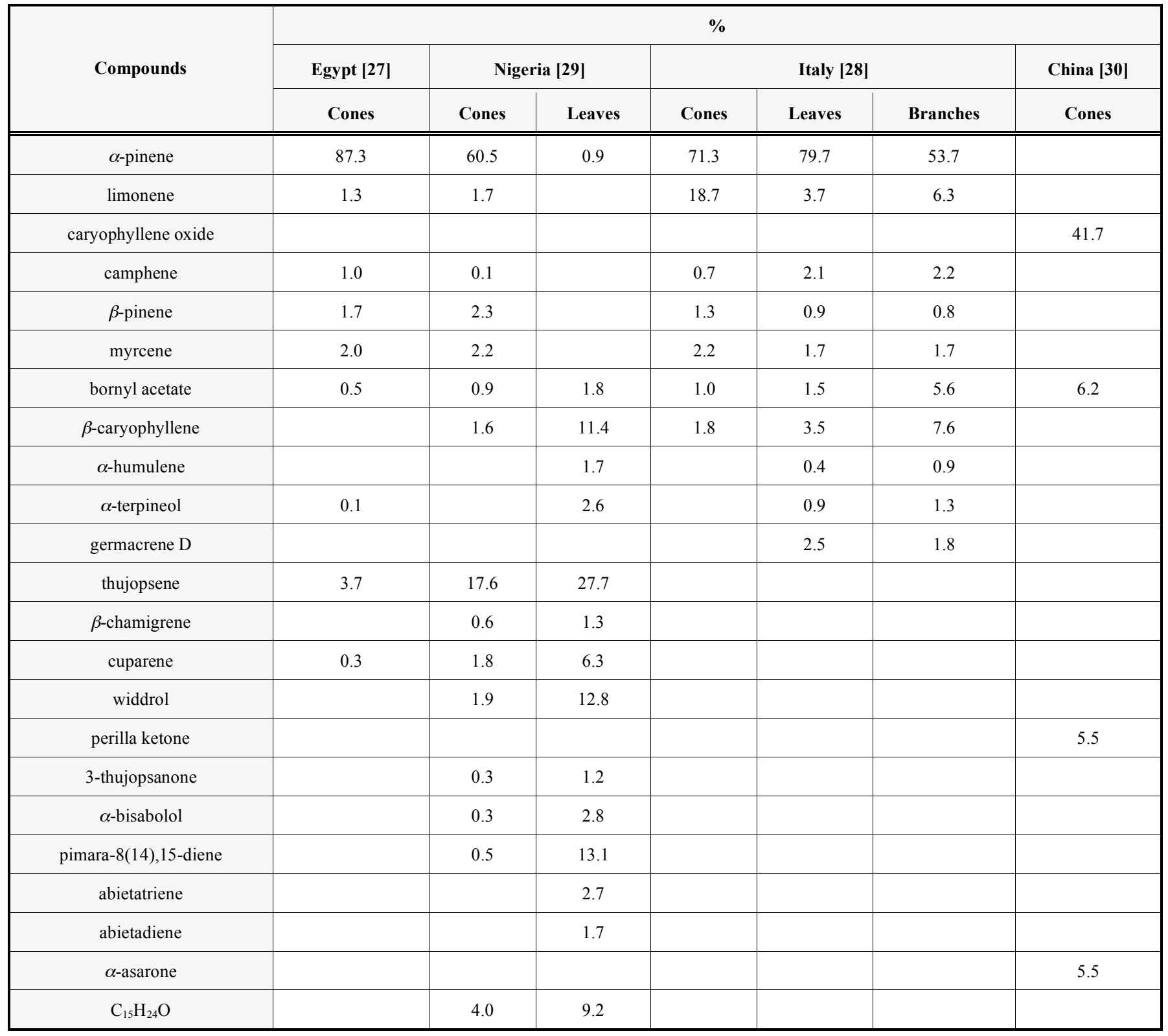

information and selectivity available from mass spectrometry (MS) has made the combination of GC and MS more effective. GC/MS has been used for analysis of volatile organic compounds of the leaves and cones of T. distichum var. distichum from different locations (Table 1). The chemical composition of essential oils varies significantly with both plant tissues and geographical location. In Egypt, the cone oil was composed predominately of monoterpenoids with $\alpha$ pinene as the major compound. 46 compounds were detected from the essential oils obtained by steam distillation $(0.8 \%$ $\mathrm{v} / \mathrm{w})$ from the cone of the baldcypress and the major constituents included $\alpha$-pinene (87.3\%), thujopsene $(3.7 \%)$, myrcene $(2.0 \%), \beta$-pinene $(1.7 \%)$, limonene $(1.3 \%)$, and camphene (1.0\%) [27]. The compositions of the essential oil of baldcypress from Nigeria or Italy are similar to that in Egypt. However, the oils in Italy had obviously higher content in limonene and more oxygenated monoterpenoids and sesquiterpenoid hydrocarbons [28]. The oils from Nigeria contained much lower $\alpha$-pinene level but had higher thujopsene content [29]. Thujopsene was not reported in the sample from Italy. In a Chinese report, $\alpha$-pinene was not detected in the cones, and the major components are caryophyllene oxide $(41.67 \%)$, bornyl acetate $(6.24 \%)$, perilla ketone $(5.45 \%)$, and $\alpha$-asarone (5.39\%) [30]. These differences in different regions may not represent geographic variations, instead factors such as provenance, local habitat, collection season, and analytical methods may have contributed to the analytical results.

\section{Diterpenoids}

Diterpenoids are a class of natural compounds that possess a core skeleton of 20 carbones. Their formation can be rationalized by considering the different types of cyclization of geranylgeranyl diphosphate (GGPP), and they are found 
Table 2. Compounds Isolated or Identified from the Extant or Fossil Taxodium

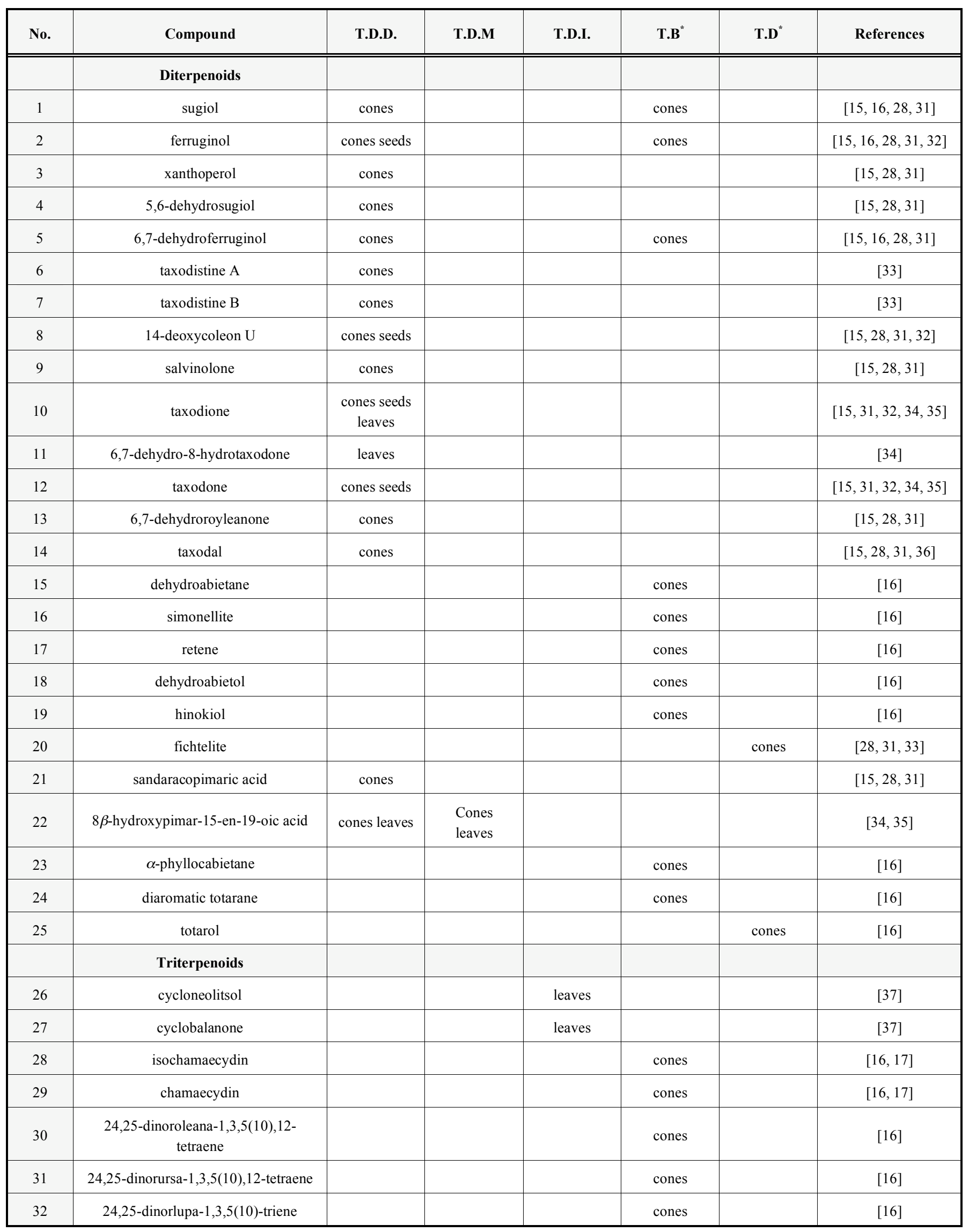


(Table 2) contd....

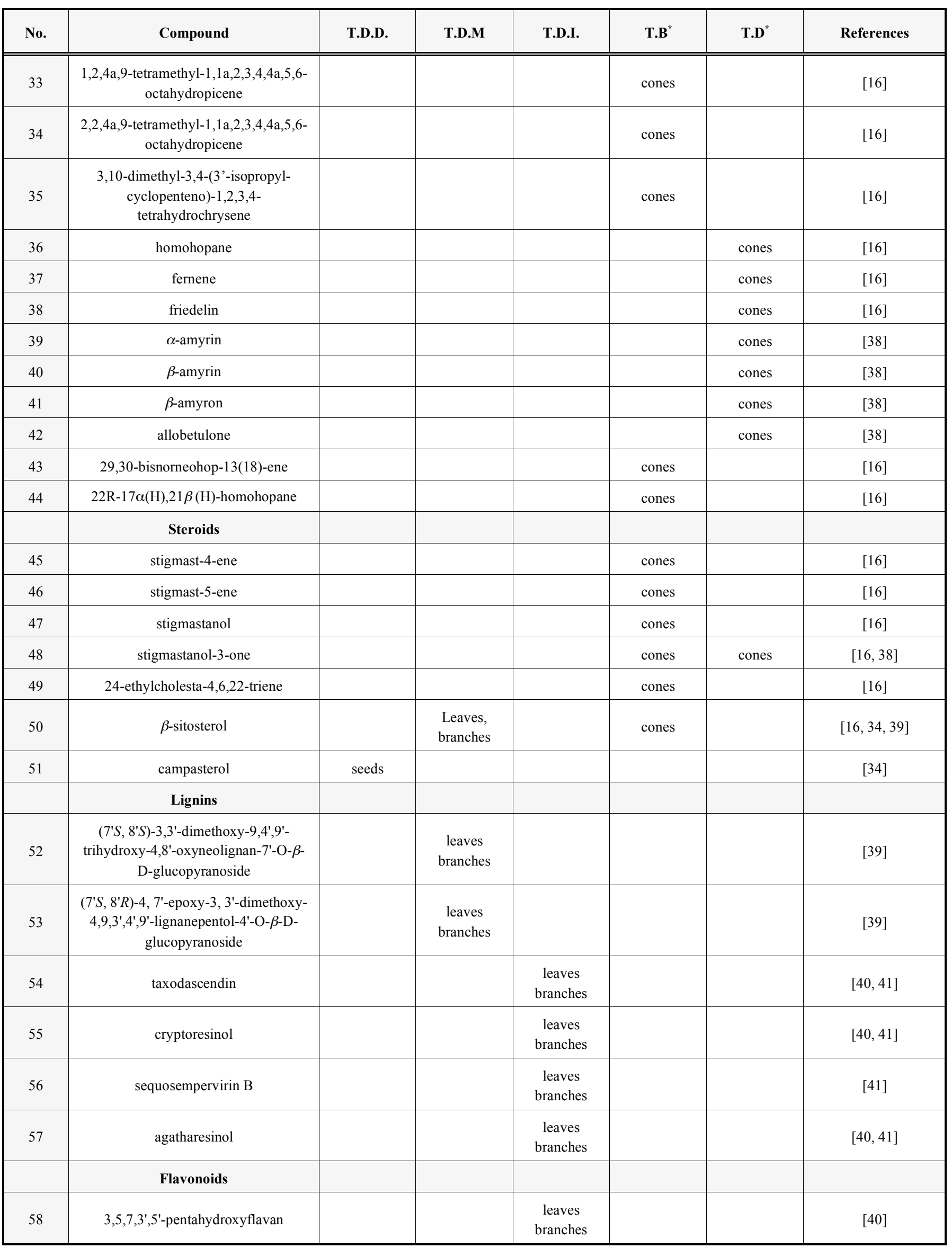


(Table 2) contd....

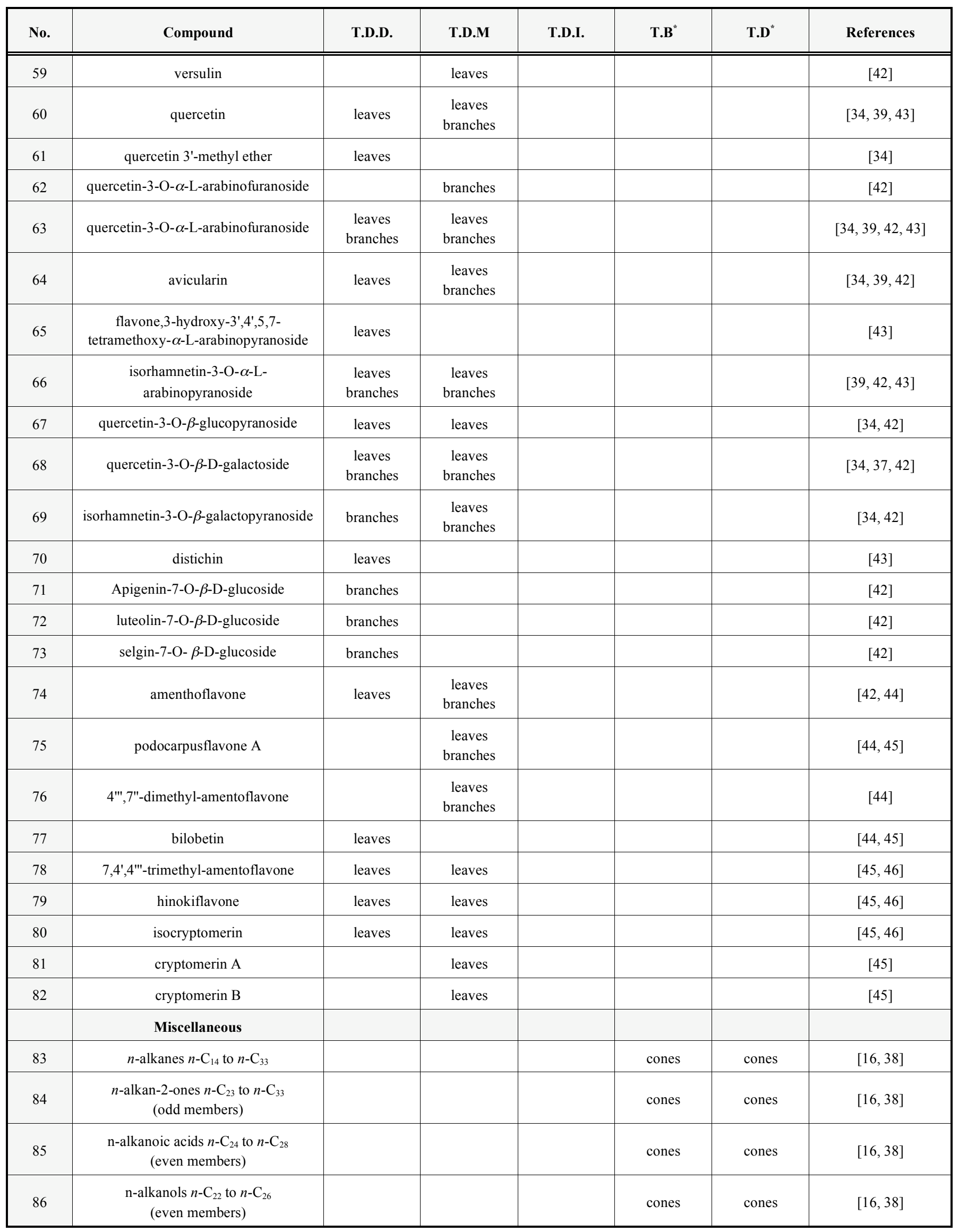


(Table 2) contd....

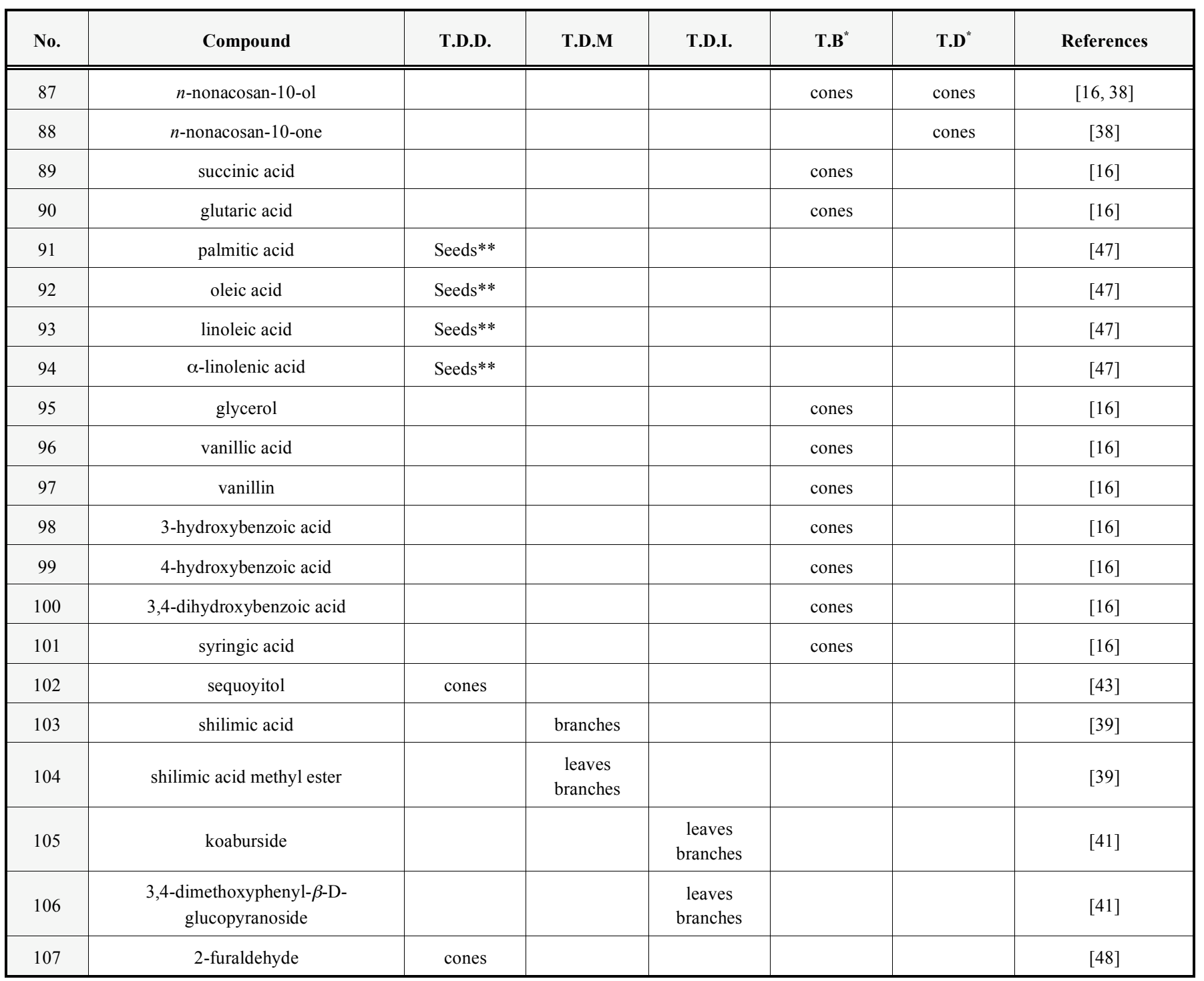

T.D.D. $=T$. distichum (L.) Rich. var. distichum (synonymy: T. distichum var. nutans (Aiton) Sweet)

T.D.M. = T. distichum (L.) Rich. var. mexicanum (Carr.) Gord. (synonymy: T. mucronatum Ten. and T. mexicanum Carr.)

T.D.I. $=$ T. distichum (L.) Rich. var. imbricarium (Nutt.) Croom (synonymy: T. ascendens Brongn., Cupressus disticha L. var. imbricaria Nutt.)

T.B. $=$ T. balticum

T.D. $=$ T. dubium

*identified by GC/MS from the fossil of T. balticum or T. dubium (Eocene). ** identified by open-tubular GC from the extant T. distichum var. distichum.

in many different plant families and some animals. Diterpenoids are of interest as many have been found to have biological activity; paclitaxel (taxol), cafestol, and kahweol all display anticancer properties. Diterpenoids isolated from Taxodium are a main group. Twenty-five diterpenoids were reported, including 12 compounds from the fossil cones of the T. balticum and T. dubium. According to their structure, this group is further classified into four types: abietane, pimarane, totarane, and kaurane.

Abietane-type diterpenoids: Abietane-type diterpenoids are widely distributed in the plant kingdom and have antitumor, cytotoxic, antifungal, and antibacterial activities. It is known that the abietane-type diterpenoids are the major compounds in the cones of Taxodium species (Table 2; Fig. 2). The earlier novel diterpenoid quinone methide tumor inhibitors, taxodione (10) and taxodone (12) were isolated from T. distichum var. distichum in 1968 [22]. Other major abietane-type diterpenoids isolated from the cones of $T$. distichum var. distichum cones include sugiol (1), ferruginol (2), 6,7-dehydroferruginol (5), taxodistine A (6), taxodistine B (7), 14-deoxycoleon U (8), and salvinolone (9) [31, 33, 36]. The irregular abietane-type diterpenoid denominated taxodal (14) from the cones of T. distichum var. distichum [36] is valuable for understanding the biosynthesis of abietane-type diterpenoids in plants. It is interesting to emphasize that sugiol (1), ferruginol (2), and 6,7-dehydroferruginol (5) have been identified in the extract of the fossil T. balticum $[16,38]$.

Pimarane-type diterpenoids: According to the recent report of Porto et al. [49], "the pimarane-type diterpenoids can potentially be another important source of secondary plant metabolites for the development of new anti-infective agents against microorganisms responsible for caries disease. In this subgroup, only two pimarane-type diterpenoids 
<smiles>CC(C)c1cc2c(cc1O)[C@@]1(C)CCCC(C)(C)[C@H]1CC2=O</smiles>

1<smiles>COC1c2cc(C(C)C)c(O)c(O)c2[C@@]2(C)CCCC(C)(C)C2C1O</smiles>

6<smiles>CC(C)C1=CC23C=C(O)[C@H]4C(C)(C)CCC[C@]4(C)C2=C(O)C(=O)C3=C1</smiles>

11<smiles>CC(C)c1ccc2c3c(ccc2c1)C(C)(C)CCC3</smiles>

16<smiles>CC(C)c1cc2c(cc1O)[C@]1(C)CCCC(C)(C)[C@H]1CC2</smiles>

2

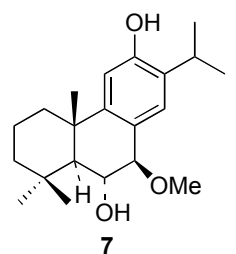<smiles>CC(C)C1=CC2=CC[C@H]3C(C)(C)CCC[C@]3(C)C2=C(O)C1=O</smiles>

12<smiles>Cc1cccc2c1ccc1cc(C(C)C)ccc12</smiles>

17<smiles>CC(C)c1cc2c(cc1O)[C@@]1(C)CCCC(C)(C)[C@]1(C)C(=O)C2=O</smiles><smiles>CC(C)c1cc2c(c(O)c1O)[C@@]1(C)CCCC(C)(C)C1=C(O)C2=O</smiles>

8<smiles>CC(C)C1=C(O)C(=O)C2=C(C=C[C@@H]3C(C)(C)CCC[C@@]23C)C1=O</smiles>

13<smiles>CC(C)c1ccc2c(c1)CCC1C(C)(CO)CCCC21C</smiles>

18<smiles>CC(C)c1cc2c(cc1O)[C@]1(C)CCCC(C)(C)C1=CC2=O</smiles>

4<smiles>CC(C)c1cc2c(c(O)c1O)[C@@]1(C)CCCC(C)(C)C1=CC2=O</smiles>

9<smiles>Cc1cc(C(C)C)c(O)cc1C1(C)CCCC(C)(C)C1=O</smiles>

14<smiles>CC(C)c1cc2c(cc1O)[C@]1(C)CC[C@@H](O)C(C)(C)C1CC2</smiles>

19<smiles>CC(C)c1cc2c(cc1O)[C@]1(C)CCCC(C)(C)[C@H]1C=C2</smiles>

5<smiles>CC(C)C1=CC2=CC(=O)[C@H]3C(C)(C)CCC[C@]3(C)C2=C(O)C1=O</smiles>

10<smiles>CC(C)c1ccc2c(c1)CCC1C2CCCC1(C)C</smiles>

15<smiles>CC1CCC[C@]2(C)C1CCC1C[C@H](C(C)C)CCC12</smiles>

20

Fig. (2). Abietane-type diterpenoids identified from Taxodium.

(Table 2; Fig. 3), sandaracopimaric acid (21) and $8 \beta$ hydroxypimar-15-en-19-oic acid (22) were identified from the cones and leaves of $T$. distichum var. distichum [28, 37] and the latter was also found in var. mexicanum [35].

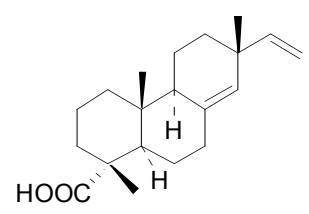

21

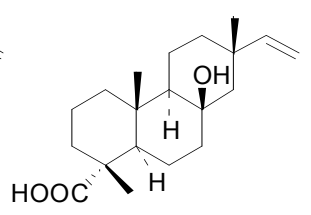

22
Fig. (3). Pimarane-type diterpenoids isolated from Taxodium.

Kaurane- and totarane-type Diterpenoids: These two subgroups are rare in the genus Taxodium, only three compounds (Table 2; Fig. 4), $\alpha$-phyllocladane (23), diaromatic totarane (24), and totarol (25), were identified from the fossil T. balticum or T. dubium by GC-MS analysis [16, 38].

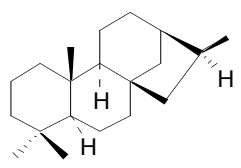

23

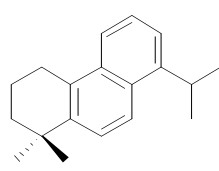

24

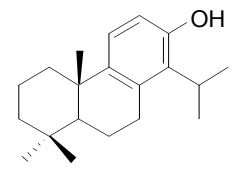

25
Fig. (4). Kaurane and totarane-type diterpenoids identified from fossil Taxodium balticum or T. dubium.

\section{Triterpenoids}

Most triterpenoids were reported in the fossil Taxodium (Table 2; Fig. 5). Some aromatic triterpenoids (28-35) were detected in the cones of $T$. balticum extracts [16, 17, 38]. Those aromatic triterpenoid hydrocarbons are comprised of monoaromatic derivatives of the oleanane, ursane, and lupine series. Two compounds isochamaecydin (28) and chamaecydin (29) with a molecular mass of 448 daltons and similar mass spectra are detected as major components in the aromatic fraction from the seed cones of T. balticum from clays of the Eocene Zeitz formation in Germany [17]. The fossil cone of $T$. balticum contains two hopanoids, 29,30bisnorneohop-13(18)-ene (43) and 22R-17 $\alpha(\mathrm{H}), 21 \beta(\mathrm{H})-$ homohopane (44) [16]. From another fossil species, T. $d u$ bium, seven triterpenoids (36-42) were detected by GC analysis [38].

To date, only two C-32 cycloartane-type triterpenoids, cycloneolitsol (26) and cyclobalanone (27), were isolated from the leaves of extant T. distichum var. imbricarium [37]. The presence of cycloartanes in T. distichum var. distichum may suggest implication for its chemotaxonomic significance in conifers [37].

\section{Steroids}

Steroids are also mainly reported in the fossils of Taxodium (Table 2; Fig. 6). Stigmast-4-ene (45), stigmast-5ene (46), stigmastanol (47), stigmastanol-3-one (48), 24 ethylcholesta-4,6,22-triene (49), and $\beta$-sitosterol (50) were 


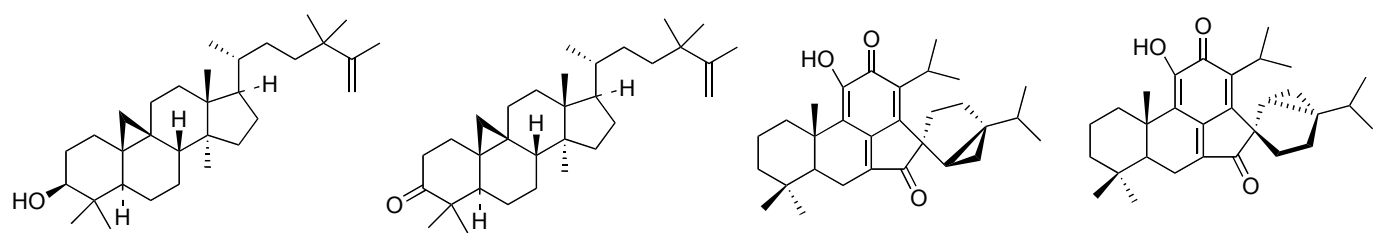<smiles>Cc1cccc2c1CCC1C2CCC2C1CCC1=C3CC(C)(C)CCC3(C)CC[C@H]12</smiles>

30<smiles>CCCC1c2c(ccc3c2ccc2c(C)cccc23)C2CC[C@H]1C2C(C)C</smiles>

35<smiles>CCCC1CCC2(C)CC[C@H]3C(CCC4c5cccc(C)c5CCC43)C2=C1C</smiles>

31<smiles>Cc1cccc2c1CCC1C3CCC4C(C(C)C)CCC4(C)CCC3C1C2</smiles>

32
28<smiles>Cc1cccc2c1ccc1c3c(ccc12)C1C(C)[C@H](C)CCC1(C)CC3</smiles>

33
29<smiles>Cc1cccc2ccc3c4c(ccc3c12)C1C2=C4CC(CC2)CCC1C</smiles>

34

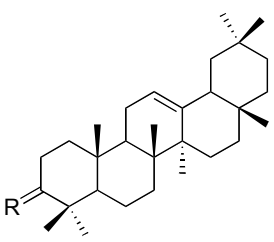

36

37

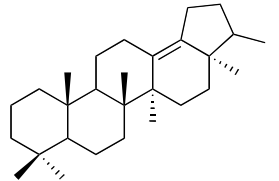

43

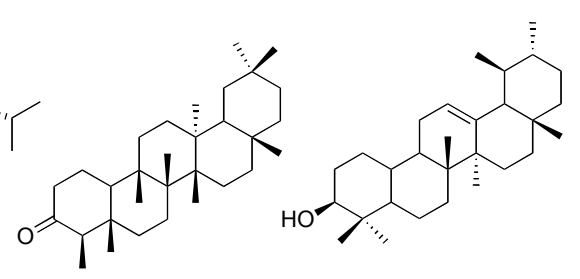

38

39

$40 \mathrm{R}=\mathrm{OH}, \mathrm{H}$
$41 \mathrm{R}=\mathrm{O}$

42

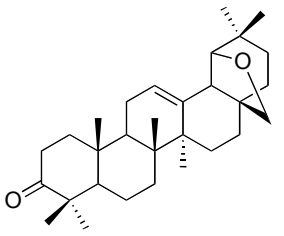

42<smiles>CCC(C)C1CCC2=C3CCC4C(CCC3[C@@]4(C)CCC3C(C)(C)CCC[C@]23C)C1(C)C</smiles>

44

Fig. (5). Triterpenoids identified from Taxodium.

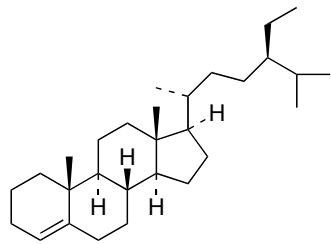

45

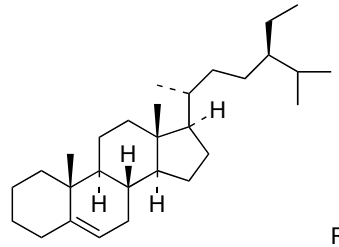

46

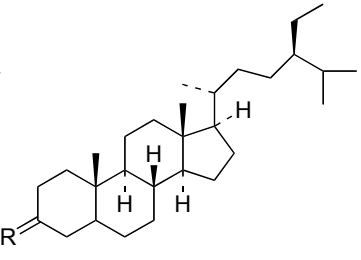

$47 \mathrm{R}=\mathrm{OH}, \mathrm{H}$

$48 \mathrm{R}=0$

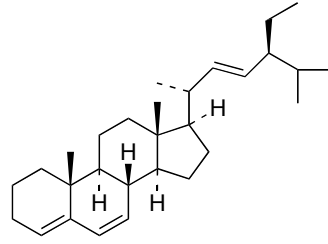

49

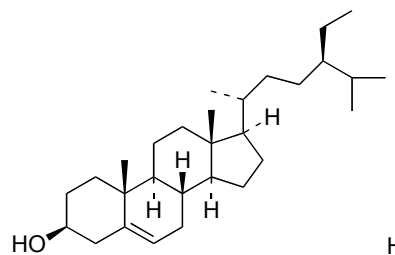

50

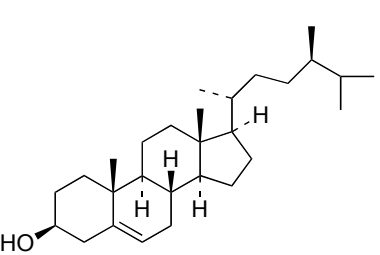

51

Fig. (6). Steroids isolated from Taxodium.

identified from the fossil cones of T. balticum with stigmastanol-3-one (48) in $T$. dubium $[16,38]$. These compounds are nonspecific markers because the biological precursor $\beta$ sitosterol (50) is ubiquitous. $\beta$-Sitosterol (50) and campesterol (51) were isolated from the leaves and branches of $T$. distichum var. mexicanum and the seeds oil of $T$. distichum var. distichum, respectively [34, 39].

\section{Lignins}

To data, six lignins have been isolated and identified from the extant Taxodium (Table 2; Fig. 7). Two lignin derivatives, (7'S, 8'S)-3,3'-dimethoxy-9,4',9'-trihydroxy-4,8'oxyneolignan-7'-O- $\beta$-D-glucopyranoside (52) and ( $\left.7^{\prime} \mathrm{S}, 8^{\prime} \mathrm{R}\right)$ 4,7'-epoxy-3,3'-dimethoxy-4,9,3',4',9'-lignanepentol-4'-O- $\beta$ D-glucopyranoside (53) have been isolated from the leaves 
<smiles>COc1cc(C2Oc3c(OC)cc(O)cc3[C@@H]2CO)ccc1O[C@@H]1O[C@H](CO)[C@@H](O)[C@H](O)[C@H]1O</smiles>

52<smiles>CC1OC(c2ccc(O)cc2)C=C1c1ccc(O)cc1</smiles>

55<smiles>COc1cc(C(O[C]2O[C@H](O)[C@@H](O)[C@H](O)[C@H]2O)C(C)Oc2ccc(O)cc2O)ccc1O</smiles>

53<smiles>COc1cc(C(O)(/C=C/c2ccc(O)cc2)CO)ccc1O</smiles>

56<smiles>Oc1ccc(C2CC[C@@H](O)C(c3ccc(O)cc3)[C@H]2O)cc1</smiles>

54<smiles>OC[C@H](O)[C@H](/C=C/c1ccc(O)cc1)c1ccc(O)cc1</smiles>

57

Fig. (7). Lignins isolated from Taxodium.

and branches of T. distichum var. mexicanum [39]. Four norlignans (54-57) have been isolated from the branches and leaves of $T$. distichum var. imbricarium [40, 41]. No report on lignins from $T$. distichum var. distichum is available.

\section{Flavonoids}

Flavonoids are a group of uniquitous and diverse molecules produced via the phenylpropanoid pathway in higher plants, and about $2 \%$ of all the photosynthesized carbon is converted into flavonoids [50]. Flavonoids are one of the main components of the genus Taxodium. A total of 25 flavonoids including flavanone, flavone and their glycosides, flavonol and their glycosides, and biflavones have been isolated from extant Taxodium (Table 2; Fig. 8). The sugars in Table 2 are assumed to be in the furanose form and have the $\alpha$-linkage for arabinose, and in the pyranose form have the $\beta$-linkage for glucoside and galactose. Quercetin (60), avicularin (64), isorhamnetin-3-arabinoside (66), and distichin (70), were identified from the leaves of $T$. distichum var. distichum [43]. Two flavonoid glycosides, quercetin 3-O- $\beta$ D-glucoside (67) and quercetin 3-O- $\beta$-D-galactoside (68) were isolated from extract of leaves of $T$. distichum var. mexicanum [35]. Walter et al. reported 10 flavone and flavonol glycosides from the branches of T. distichum var. distichum [42]. Nine biflavones (74-82) composing of two apigenins or its patial methyl ester via C-C (8-3') or C-O (6-4') linkage were isolated from the leaves and branches of $T$. distichum var. distichum and var. mexicanum [44-46].

\section{Other Compounds}

The aliphatic lipids including $n$-alkanes $\left(n-\mathrm{C}_{14}\right.$ to $\left.n-\mathrm{C}_{33}\right)$ (83), $n$-alkan-2-ones $\left(n-\mathrm{C}_{23}\right.$ to $n$ - $\left.\mathrm{C}_{33}\right)(\mathbf{8 4}), n$-alkanoic acids $\left(n-\mathrm{C}_{24}\right.$ to $\left.n-\mathrm{C}_{28}\right)(\mathbf{8 5})$, $n$-alkanol $\left(n-\mathrm{C}_{22}\right.$ to $\left.n-\mathrm{C}_{26}\right)(\mathbf{8 6}), n$ nonacosan-10-ol (87), and $n$-nonacosan-10-one (88), succinic acid (89), and glutaric acid (90) were identified in the extract of fossil Taxodium (Table 2; Fig. 9) by GC/MS analysis $[16,38]$. Among them, the $n$-nonacosan-10-ol (87), and its ketone $n$-nonacosan-10-one $(\mathbf{8 8})$ were abundant in fossils [16, 38]. In addition, polyol (95) or polyphenols (96101) were detected from the fossil T. balticum [16].

Extant Taxodium contain chemical components similar to fossils. Open-tubular GC analysis of the seeds of extant $T$. distichum var. distichum indicated that palmitic acid (91), oleic acid (92), linoleic acid (93), and $\alpha$-linolenic acid (94) are major lipids with nonmethylene-interrupted polyenoic (NMIP) acids as minor compounds [47]. Sequoyitol (102) and shilimic acid (103) have been isolated from the leaves of T. distichum var. distichum [34, 43], and the methyl ester of shilimic acid (104) was isolated from the leaves and branches of $T$. distichum var. mexicanum (Table 2) [39]. Two phenylglucosides (105-106), koaburside and 3,4dimethoxyphenyl- $\beta$-D-glucopyranoside were isolated from the branches and leaves of $T$. distichum var. imbricarium [41]. 2-furaldehyde (107) was isolated from baldcypress in 1981 [48] (Table 2; Fig. 9). It was also reported that T. distichum var. distichum contains proanthocyanidins in leaves [51], polysaccharides in wood [52], and tannins and polyphenols in wood and bark [53].

\section{BIOLOGICAL AND PHARMACOLOGICAL ACTIVI- TIES}

Ethnobotanical uses of Taxodium have been well documented and there are also interests for further investigation of the Taxodium and the isolated compounds in term of modern medicine. The existing biological and pharmacological reports of Taxodium are primarily restricted to in vitro activities. In fact, the biological and pharmacological properties of Taxodium extracts and isolates cannot be fully understood without extensive investigations in the chemical constituents of extant taxa.

\section{Antimicrobial Activities}

The essential oil from the cones of baldcypress trees grown exhibited potent antimicrobial activities against bacteria Bacillus subtilis (ATCC 6633), Stapbylococcus aureus (ATCC 6536), Pseudomonas aeruginosa (ATCC 27853), Escherichia coli (ATCC 25922), Proteus mirabtlis (ATCC 4630), Klebsiella pneumonia (ATCC 10031), and Citrbacter diwersus (CI 98) and the fungus Candida albicanswas (ATCC 32354) [27]. However, it is interesting that the oil of the leaves and cones collected from Nigeria exhibited only weak antibacterial activities against B. cereus (ATCC 14579), S. aureus (ATCC 29213), P. aeruginosa (ATCC 27853), and E. coli (ATCC 25922) (MIC >150 $\mu \mathrm{g} / \mathrm{mL}$ ) but potent activity against the fungus Aspergillus niger (ATCC 
<smiles>Oc1cc(O)cc(C2Oc3cc(O)cc(O)c3CC2O)c1</smiles>

58<smiles>[R]c1cc(-c2oc3cc(O)cc(O)c3c(=O)c2O[C@H]2OC[C@@H](O)[C@H](O)[C@H]2O)ccc1O</smiles>
$64 \mathrm{R}=\mathrm{OH}$
$65 \mathrm{R}=\mathrm{OCH}_{3}$<smiles>COc1cc(-c2oc3cc(O)cc(O)c3c(=O)c2OC2CC(O)C(O)CO2)ccc1O</smiles>

70

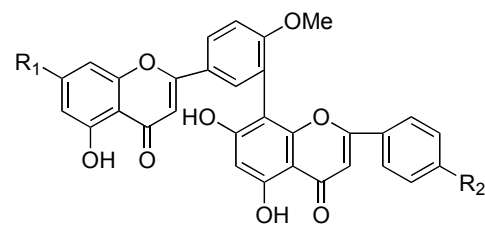

$77 \mathrm{R}_{\mathbf{1}}=\mathrm{R}_{\mathbf{2}}=\mathrm{OH}$

$78 R_{1}=R_{2}=O^{O C H}$<smiles>O=c1cc(-c2ccc(O)cc2)oc2cc(O)cc(O)c12</smiles><smiles>[R]c1cc(-c2oc3cc(O)cc(O)c3c(=O)c2O)ccc1O</smiles><smiles>[R]c1cc(-c2oc3cc(O)cc(O)c3c(=O)c2O[C@@H]2O[C@H](CO)[C@@H](O)[C@H]2O)ccc1O</smiles>

59

$$
60 \mathrm{R}=\mathrm{OH}
$$

$61 \mathrm{R}=\mathrm{OCH}_{3}$<smiles></smiles>

66<smiles>[R]c1cc(-c2cc(=O)c3c(O)cc(O[C@@H]4O[C@H](CO)[C@@H](O)[C@H](O)[C@H]4O)cc3o2)cc([R2])c1O</smiles>

$$
71 R_{1}=R_{2}=H
$$$$
72 \mathrm{R}_{1}=\mathrm{H}, \mathrm{R}_{2}=\mathrm{OH}
$$

$73 \mathrm{R}_{1}=\mathrm{OH}, \mathrm{R}_{2}=\mathrm{OCH}_{3}$<smiles>O=c1c(O[C@H]2OC(CO)[C@@H](O)[C@H](O)[C@H]2O)c(-c2ccc(O)c(O)c2)oc2cc(O)cc(O)c12</smiles>

67<smiles>[R]c1ccc(-c2cc(=O)c3c(O)c(Oc4ccc(-c5cc(=O)c6c(O)cc(O)cc6o5)cc4)c([R])cc3o2)cc1</smiles>

$79 \mathrm{R}_{1}=\mathrm{R}_{2}=\mathrm{OH}$

$80 \mathrm{R}_{1}=\mathrm{OCH}_{3}, \mathrm{R}_{2}=\mathrm{OH}$

$81 \mathrm{R}_{1}=\mathrm{OH}, \mathrm{R}_{2}=\mathrm{OCH}_{3}$

$82 \mathrm{R}_{1}=\mathrm{R}_{\mathbf{2}}=\mathrm{OCH}_{3}$

Fig. (8). Flavonoids isolated from Taxodium.

16401) (19.5 $\mu \mathrm{g} / \mathrm{mL})$ [29]. The difference in antibacterial activity of the oils between the two reports cannot be simply attributed to the higher content of $\alpha$-pinene in Egypt samples (Table 1) because this compound has a weak antibacterial effect [29].

Non-essential oils in Taxodium also showed antimicrobial activities. The methanol extract of the Montezuma cypress showed potent antibacterial activity and may have potential in the treatment of gastrointestinal disorders caused by Helicobacter pylori [54]. Accumulating evidence indicates that diterpenoids are a group of primary active compounds responsible for antimicrobial activities of Taxodium. Two diterpenoids obtained from other sources but commonly occurred in the cones of Taxodium showed antibacterial activities. Taxodione (10) was reported to exhibit antibacterial activities against methicillin-resistant $S$. aureus (MRSA) and vancomycin-resistant Enterococcus (VRE) [31]. Sugiol (1) showed antibacterial effect against foodborne pathogens and detrimental effect on morphology of Listeria monocytogenes [55]. Taxodione (10) and 14-deoxycoleon U (8) isolated from the cones of baldcypress were found highly active against both wood-decay fungi Trametes versicolor (white- rot) and Fomitopsis palustris (brown-rot) [56]. The SAR analysis of the diterpenoids suggests a strong relationship between the positions of hydroxyl group and antifungal activity [28]. Two abietane-type diterpenoids with quinone structures at the $\mathrm{C}$ rings, cryptoquinone and 7-hydroxy11,14-dioxo-8,12-abietadiene, obtained from other sources were also reported to have antifungal activities [22, 23, 31].

\section{Cytotoxicities}

There are only few reports on cytotoxicities of extracts or isolates from Taxodium. The seeds of baldcypress were reported to possess bioactivities against human tumor cell lines $[22,23,57]$. The cone essential oils of baldcypress can effectively inhibit certain human tumor cells at higher dosage (inhibit $99.77 \%$ of prostate tumor PC-3 cells at $100 \mu \mathrm{g} / \mathrm{mL}$, $100 \%$ of liver tumor Hep G2 cells at $250 \mu \mathrm{g} / \mathrm{mL}$, and $100 \%$ of breast (ductal) tumor Hs $578 \mathrm{~T}$ cells at $250 \mu \mathrm{g} / \mathrm{mL}$ ) [29]. Taxodistines A (6) and B (7) isolated from the cones of baldcypress showed cytotoxicity against murine lymphoma P388 cells at $\mathrm{IC}_{50} 0.43$ and $6.5 \mu \mathrm{g} / \mathrm{mL}$, respectively [33]. Martínez et al. reported that taxodione (10) and taxodone (12) from resins of the leaves and cones of Montezuma 


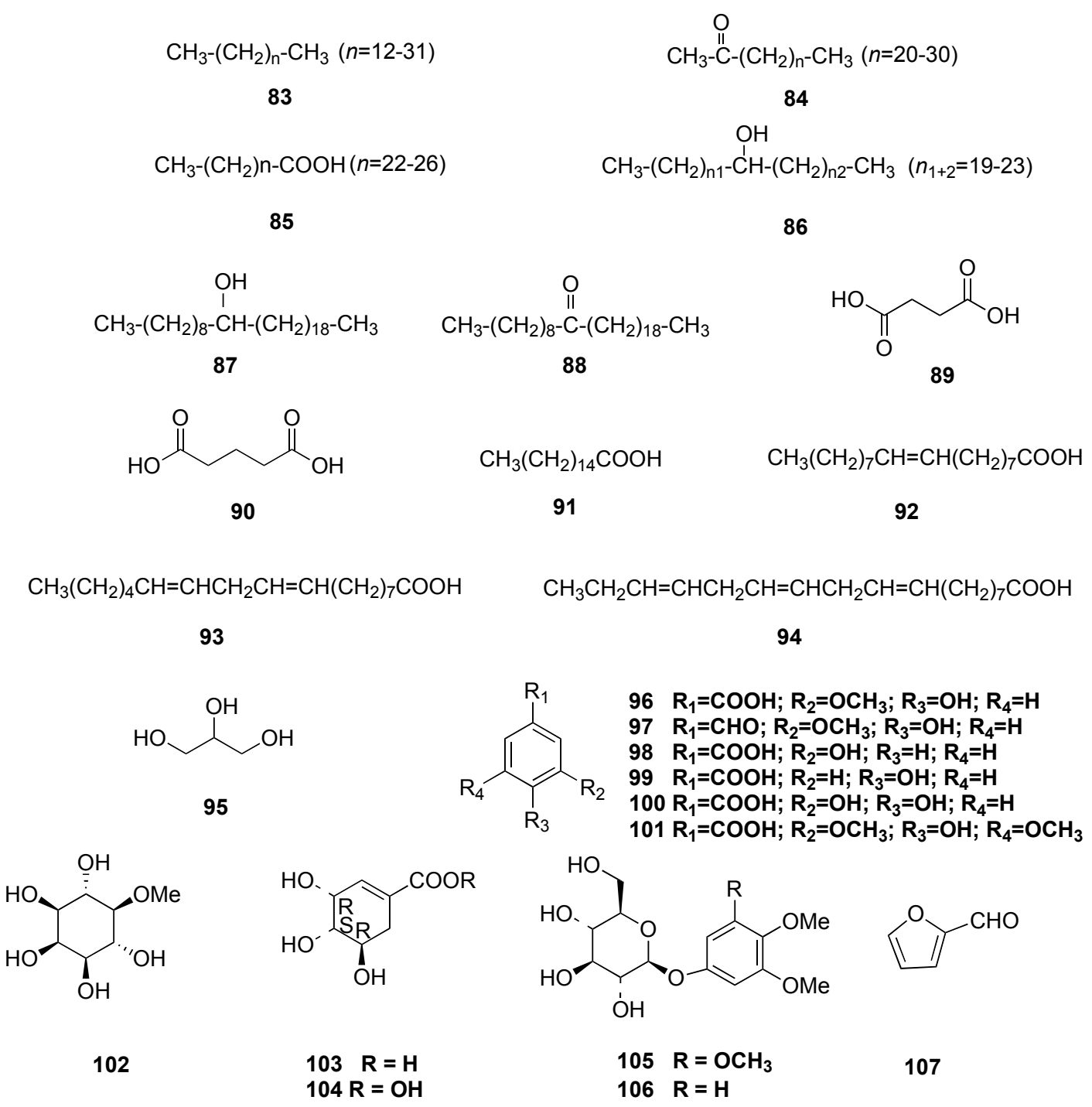

Fig. (9). Other compounds isolated from Taxodium.

cypress can cure leg tumors and reduce inflammation and rapidly resolve articular diseases. The treatment results are still yet to be independently verified and the mechanisms of action of essential oils or compounds of Taxodium as antitumor agents are essentially unknown. It was reported that the polymerization of microtubules of cells was inhibited $90 \%$ by taxodistine B (7) at the concentration of $100 \mu \mathrm{M}$, and $45 \%$ by taxodione (10) at $100 \mu \mathrm{M}$. Taxodistine A (6) did not inhibit the polymerization process at higher concentration $(200 \mu \mathrm{M})$ [31]. Methanol extract of branches and leaves of pondcypress showed inhibitory activity on carbonic anhydrase II with an $\mathrm{IC}_{50}$ value of $4.27 \mu \mathrm{g} / \mathrm{mL}$. The acetone extract and methanol extract inhibited cathepsin $\mathrm{B}$ with $\mathrm{IC}_{50}$ values of 2.12 and $3.71 \mu \mathrm{g} / \mathrm{mL}$, respectively [41]. Sugiol (1) isolated from the medicinal Peltodon longipes was shown to possess cytotoxic activity against the human pancreatic cancer cell line MIA PaCa-2, and also found the relaxation activity of human DNA topoisomerases I and II [58]. Aspects of the biological activity of sugiol (1) continues to be explored and shown to possess xanthine oxidase inhibitory activity [58]. Sugiol (1) and ferruginol (2) have near 100\% aldose reductase (AR) inhibition efficacy at concentration of 5 and $25 \mu \mathrm{M}$, respectively [59]. Ferruginol (2) showed ef- fects on gastric secretion, endogenous prostaglandins and non-protein sulfhydryls, and its mechanism of assessment of action was elevated in vitro models in mice and rats $[60,61]$. Some of natural biflavones inhibit cathepsin B and cathepsin $\mathrm{K}$, especially HIF with $\mathrm{IC}_{50}$ of $0.58 \mathrm{mM}$ against cathepsin $\mathrm{B}$ $[62,63]$. In addition, taxodione (10) also showed HIV-1 PR inhibitory activity in $0.1 \mathrm{mM}$ concentraction [32].

\section{Antitermitic Activities}

Several abietane-type diterpenoids isolated from baldcypress cones exhibited potential in termite control. 6,7Dehydroroyleanone (13) and taxodione (20) showed potent termicidal activity against the subterranean termite, Reticulitermes speratus Kolbe while 14-deoxycoleon U (8) and xanthoperol (3) showed antifeedant activity [31].

\section{Antispasmodic and Bronchodilator Activities}

The leaf hexane extract of Montezuma cypress produced a concentration-dependent relaxant effect on intestinal and tracheal smooth muscle and were evaluated in vitro by testing spontaneous contractions of rabbit jejunum and agonistinduced contractions of guinea pig ileum and rat trachea [4]. 


\section{CONCLUSIONS}

None of the three taxa of Taxodium have been extensively investigated for chemical constituents although abietane-type diterpenoids and flavonoids are reported as major compounds of the genus. To date, 57 compounds have been isolated from the three taxa of extant Taxodium with more than 60 compounds were identified from the essential oils. Interestingly, 50 compounds have been identified from the fossil Taxodium while four occur in the extant species as major compounds. The existing in vitro reports have demonstrated various biological and pharmacological activities of Taxodium. Diterpenoids from Taxodium may be further studied for their potential biological and pharmaceutical activities against inflammation and oxidative stresses associated with serious disease, such as diabetes and cardiovascular diseases. The diterpenoids identified in Taxodium have provided important and interesting evidence of evolutionary pattern and taxonomy of the genus. In fact, the abundant phenolic abietanes (sugiol (1), ferruginol (2), and 6,7dehydroferruginol (5)) in both extant and fossil Taxodium may be used as chemosystematic markers for the phylogenetic and systematic comparison of the taxa. These compounds are common in many genera of conifers and are also in some flowering plants (e.g., in Lamiaceae). To fully reveal the evolution and taxonomic puzzle as well as medicinal value of Taxodium, however, it is necessary to have systematic studies on chemical constituents of Taxodium particularly $T$. distichum var. imbricarium and var. mexicanum as well as their biological and pharmacological properties.

\section{CONFLICT OF INTEREST}

The author(s) confirm that this article content has no conflicts of interest.

\section{ACKNOWLEDGEMENT}

This work was funded by Stephen F. Austin State University.

\begin{tabular}{|c|c|c|}
\hline \multicolumn{3}{|c|}{ ABBREVIATIONS } \\
\hline $\mathrm{GC}$ & $=$ & Gas chromatography \\
\hline GC/MS & $=$ & Gas chromatography-mass spectroscopy \\
\hline GGPP & $=$ & Geranylgeranyl diphosphate \\
\hline Hep G2 & $=$ & A human liver tumor cell line \\
\hline HIF & $=$ & Hypoxia-inducible factor \\
\hline HPLC & $=$ & $\begin{array}{l}\text { High performance liquid chromatogra- } \\
\text { phy }\end{array}$ \\
\hline MIA PaCa-2 & $=$ & A human pancreatic carcinoma cell line \\
\hline MRSA & $=$ & $\begin{array}{l}\text { Methicillin-resistant Stapbylococcus } \\
\text { aureus }\end{array}$ \\
\hline NMIP & $=$ & Nonmethylene-interrupted polyenoic \\
\hline P388 & $=$ & A murine lymphoma cell line \\
\hline PC-3 & $=$ & A human prostate cancer cell line \\
\hline SAR & $=$ & Structure activity relationship \\
\hline TLC & $=$ & Thin layer chromatography \\
\hline
\end{tabular}

UPLC = Ultra performance liquid chromatography

VRE $=$ Vancomycin-resistant Enterococcus

\section{REFERENCES}

[1] Watson, F.D. Taxodium. In: Flora of North America North of Mexico, Committee, F. o. N. A. E., Ed. Oxford University Press: New York, Oxford, 1993; vol. 2.

[2] Scheffrahn, R.H.; Hsu, R.C.; Su, N.Y.; Huffman, J.B.; Midland, S.L.; Sims, J.J. Allelochemical resistance of Bald Cypress, Taxodium distichum, heartwood to the subterranean termite, Coptotermes formosanus. J. Chem. Ecol., 1988, 14, 765-776.

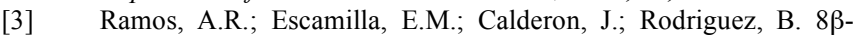
Hydroxypimar-15-en-19-oic acid from Taxodium mucronatum. Phytochemistry, 1984, 23 (6), 1329-1330.

[4] Cortés-Arroyo, A.R.; Domínguez-Ramírez, A.M.; GómezHernández, M.; Medina López, J.R.; López-Muñoz, F.J. Antispasmodic and bronchodilator activities of Taxodium mucronatum Ten leaf extract. Afr. J. Biotechnol., 2011, 10, 54-64.

[5] Turner, R.G. Jr; Watson, E. Botanica. Barnes \& Noble, Inc.: New York, 1999.

[6] Farjon, A. A monograph of Cupressaceae and Sciadopites. Royal Botanic Gardens, Kew Press: London, 2005.

[7] Vines, R.A. Trees, shrubs and woody vines of the Southwest: A guide for the states of Arkansas, Louisiana, New Mexico, Oklahoma, and Texas. University of Texas Press: Austin, 1960.

[8] Adams, R.P.; Arnold, M.A.; King, A.R.; Denny, G.C. Geographic variation in the leaf essential oils of Taxodium (Cupressaceae). Phytologia, 2012, 94 (1), 53-70.

[9] Diggs, G.M.; Lipscomb, B.L.; Reed, M.D.; O'Kennon, R.J. Illustrated flora of East Texas. $1^{\text {st }}$ ed.; Botanical Research Institute of Texas and Austin College: Fort Worth, TX, 2006.

[10] Tsumura, Y.; Tomaru, N.; Suyama, Y.; Bacchus, S. Genetic diversity and differentiation of Taxodium in the south-eastern United States using cleaved amplifies polymorphic sequences. Heredity, 1999, 83, 229-238.

[11] Lickey, E.B.; Walker, G.L. Population genetic structure of baldcypress (Taxodium distichum [L.] Rich. var. distichum) and pondcypress (T. distichum var. imbricarium [Nuttall] Croom): Biogeographic and taxonomic implications. Southeast. Nat., 2002, 1, 131-148.

[12] Adams, R.P.; Arnold, M.A.; King, A.R.; Denny, G.C.; Creech, D. Taxodium (Cupressaceae): one, two or three species? Evidence from sequences and terpenoids. Phytologia, 2012, 94 (2), 159-168.

[13] Middleton, B.L.; McKee, K.L. Use of a latitudinal gradient in bald cypress (Taxodium distichum) production to examine physiological controls of biotic boundaries and potential responses to environmental change. Glob. Ecol. Biogeogr., 2004, 13, 247-258.

[14] Denny, G.C. Evaluation of selected provenances of Taxodium distichum for drought, alkalinity and salinity tolerance. $\mathrm{PhD}$ Thesis, A\&M University: Texas, 2007.

[15] Kusumoto, N.; Ashitani, T.; Murayama, T.; Ogiyama, K.; Takahashi, K. Antifungal abietane-type diterpenes from the cones of Taxodium distichum Rich. J. Chem. Ecol., 2010, 36 (12), 13811386.

[16] Otto, A.; Simoneit, B.R.T. Chemosystematics and diagenesis of terpenoids in fossil conifer species and sediment from the Eocene Zeitz formation, Saxony, Germany. Geochim. Cosmochim. Acta, 2001, 65, 3505-3527.

[17] Otto, A.; White, J.D.; Simoneit, B.R.T. Natural product terpenoids in Eocene and Miocene conifer fossils. Science, 2012, 297, 15431545.

[18] Chan, S.C.; Chang, Y.S.; Wang, J.P.; Chen, S.H.; Kuo, S.C. Three new flavonoids and antiallergic, anti-Inflammatory constituents from the heartwood of Dalbergia odorifera. Planta Med., 1998, 64 (2), 153-158.

[19] Contreras-Medina, R.; Luna-Vega, I. Species richness, endemism and conservation of Mexican gymnosperms. Biodivers. Conserv., 2007, 16, 1803-1821.

[20] Locklear, J.R. Fossil Taxodium seeds and palynological assessment of a Pleistocene age locality from southeastern North Carolina. Master Thesis. North Carolina State University: Raleigh, North Carolina, 2011. 
[21] Sharaf, M. An English Arabic Dictionary of Medicine, Biology and Allied Science. Government Press: Cairo, 1928, p. 878.

[22] Kupchan, S.M.; Karim, A.; Marcks, C. Taxodione and taxodone, two novel diterpenoid quinone methide tumor inhibitors from Taxodium distichum. J. Am. Chem. Soc., 1968, 90 (21), 5923-5924.

[23] Kupchan, S.M.; Karim, A.; Marcks, C. Tumor inhibitors. XLVIII. Taxodione and taxodone, two novel diterpenoid quinone methide tumor inhibitors from Taxodium distichum J. Org. Chem., 1969, 34 (12), 3912-3918.

[24] Martínez, M. Las Plantas Medicinales de México. Tomo I. 7 a ed., Ediciones Botas: México, 2005, 29-32.

[25] Andrade-Cetto, A.; Heinrich, M. Mexican plants with hypoglycaemic effect used in the treatment of diabetes. $J$. Ethnopharmacol., 2005, 99, 325-348.

[26] Perusquía, M.; Mendoza, S.; Bye, R.; Linares, E.; Mata, R. Vasoactive effects of aqueous extracts from five Mexican medicinal plants on isolated rat aorta. J. Ethnopharmacol., 1995, 46, 63-69.

[27] EI Tantawy, M.E.; El Sakhawy, F.S.; EI Sow, M.; Ross, S.A. Chemical Composition and Biological Activity of the Essential Oil of the Fruit of Taxodium distichurn L. Rich Growing in Egypt. $J$. Essent. Oil Res., 1999, 11, 386-392.

[28] Flamini, G.; Cioni, P.L.; Morelli, I. Investigation of the essential oil of feminine cones, leaves and branches of Taxodium distichum from Italy. J. Essent. Oil Res., 2000, 12, 310-312.

[29] Ogunwande, I.A.; Olawore, N.O.; Ogunmola, O.O.; Walker, T.M.; Schmidt, J.M.; Setzer, W.N. Cytotoxic effects of Taxodium distichum oils. Pharm. Biol., 2007, 45 (2), 106-110.

[30] Zhou, Y.J.; Gao, W.; Rong, Q.; Jin, G.; Chu, H.; Liu, W.; Yang, W.; Zhu, Z.; Li, G.; Zhu, G.; Huang, L.; Zhao, Z.K. Modular pathway engineering of diterpenoid synthases and the mevalonic acid pathway for Miltiradiene production J. Am. Chem. Soc., 2012, 134 (6), 3234-3241.

[31] Kusumoto, N.; Ashitani, T.; Hayasaka, Y.; Murayama, T.; Ogiyama, K.; Takahashi, K. Antitermitic activities of abietane-type diterpenes from Taxodium distichum cones. J. Chem. Ecol., 2009, 35 (6), 635-642.

[32] Ahmed, A.S.; Ei-Emary, N.A. Biologically active abietane diterpenes from Taxodium distichum seeds. Bull. Pharm. Sci., Assiut Univ., 1999, 22 (1), 21-25.

[33] Hirasawa, Y.; Izawa, E.; Matsuno, Y.; Kawahara, N.; Goda, Y.; Morita, H. Taxodistines A and B, abietane-type diterpenes from Taxodium distichum. Bioorg. Med. Chem. Lett., 2007, 17 (21), 5868-5871.

[34] Zaghloul, A.M.; Gohar, A.A.; Naiem, Z.A.A.M.; Abdel Bar, F.M. Taxodione, a DNA-binding compound from Taxodium distichum L. (Rich.). J. Biosci., 2008, 63 (5/6), 355-360.

[35] Khabir, M.; Khatoon, F.; Ansari, W.H. Flavonoid glycosides from the leaves of Taxodium mucronatum. J. Indian Chem. Soc., 1986, 63 (8), 781-782.

[36] Kusumoto, N.; Murayama, T.; Kawai, Y.A.; Tatsuya; Ogiyama, K.; Takahashi, K. Taxodal, a novel irregular abietane-type diterpene from the cones of Taxodium distichum. Tetrahedron Lett., 2008, 49 (33), 4845-4847.

[37] Si, Y.; Yao, X.H.; Zhang, C.K.; Tu, Z.B. C-32 triterpenes from Taxodium ascendens. Biochem. Syst. Ecol. , 2005, 33 (2), 211-214.

[38] Stefanova, M. Molecular indicators for Taxodium dubium as coal progenitor of "Chukurovo" lignite, Bulgaria. Bull. Geol. Soc. Greece, 2004, XXXVI, 342-347.

[39] Zhang, Y.M.; Tan, N.H. Chemical constituents of Taxodium mucronatum. Tianran Chan Wu Yan Jiu Yu Kaifa, 2007, 19 (5), $801-803,821$

[40] Li, Z.; Tan, N.; Zhang, Y.; Duan, J. Chemical constituents of Taxodium ascendens. Zhongcaoyao, 2008, 39 (5), 645-648.

[41] Zhang, Y.M.; Tan, N.H.; Zeng, G.Z.; Adebayo, A.H.; Ji, C.J. A new norlignan from Taxodium ascendens. Fitoterapia, 2009, 80 (6), 361-363.
[42] Geiger, H.; De Groot-Pfleiderer, W. Flavone and flavonol glycosides of Taxodium distichum. Phytochemistry, 1979, 18 (10), 1709-1710.

[43] Tatsuo, K.; Mitsuo, T.; Tokuuzo, I.; Koichiro, M. A newglycoside, distichin and other constituents of the leaves of Taxodium distichum. Yakugaku Zasshi, 1960, 80, 102-105.

[44] Zhang, Y.; Tan, N.; Huang, H.; Jia, R.; Zeng, G.; Ji, C. Three bioactive biflavones isolated from Taxodium mucronatum. Yunnan Zhi Wu Yan Jiu 2005, 27 (1), 107-110.

[45] Ishratullah, K.; Rahman, W.; Okigawa, M.; Kawano, N. Biflavones from Taxodium mucronatum. Phytochemistry, 1978, 17 (2), 335.

[46] Geiger, H.; De Groot-Pfleiderer, W. Biflavones of Taxodium distichum. Phytochemistry, 1973, 12 (2), 465-466.

[47] Takagi, T.; Itabashi, Y. cis-5-oleifinic unusual fatty acids in seeds lipids of gymnospermae and their distribution in triacylglycerals Lipids, 1982, 17, 716-723.

[48] Jones, C.G.; Aldrich, J.R.; Blum, M.S. 2-Furaldehyde from baldcypress: a chemical rationale for the demise of the Georgia silkworm industry. J. Chem. Ecol., 1981, 7, 89-101.

[49] Porto, T.S.; Rangel, R.; Furtado, N. A.J.C.; de Carvalho, T.C.; Martins, C.H.G.; Veneziani, R.C.S.; Da Costa, F.B.; Vinholis, A.H.C.; Cunha, W.R.; Heleno, V.C.G.; Ambrosio, S.R. Pimaranetype diterpenes: antimicrobial activity against oral pathogens. Molecules, 2009, 14, 191-199.

[50] Chen, W.H.; Wang, R.; Shi, Y.P. Flavonoids in the poisonous plant Oxytropis falcata J. Nat. Prod., 2010, 73 (8), 1398-1403.

[51] Stanford, A.H.; Lester, H.H. Proanthocyanidins in needles from six genera of the Taxodiaceae. Am. J. Bot., 1986, 73, 1555-1562.

[52] Renate, H. Composition of wood polysaccharides of different stages of age of Taxodium distichum. Holzforschung, 1971, 25, 1518

[53] Hergert, H.L. Chemical composition of tannins and polyphenols from conifer wood and bark. For. Prod. J., 1960, 10, 610-617.

[54] Robles-Zepeda, R.; Velázquez-Contreras, C.; Garibay-Escobar, A.; Gálvez-Ruiz, J.; Ruiz-Bustos, E. Antimicrobial activity of Northwestern Mexican plants against Helicobacter pylori. J. Med. Food, 2011, 14, 1280-1283.

[55] Bajpai, V.K.; Kang, S.C. Isolation and characterization of biologically active secondary metabolites from Metasequoia glyptostroboides Miki ex Hu. J. Food Saf., 2011, 31, 276-283.

[56] Yang, Z.; Kitano, Y.; Chiba, K.; Shibata, N.; Kurokawa, H.; Doi, Y.; Arakawa, Y.; Tada, M. Synthesis of variously oxidized abietane diterpenes and their antibacterial activities against MRSA and VRE. Bioorg. Med. Chem., 2001, 9, 347-356.

[57] Marcio, F.; Evelyn, L.; Stefan, G.; Berta, H.; Stefan, L.; Irmgard, M. Abietane diterpenes induce cytotoxic effects in human pancreatic cancer cell line MIA PaCa-2 through different modes of action. Phytochemistry, 2012, 78, 107-119.

[58] Lin, C.Z.; Zhu, C.C.; Zhao, Z.X.; Li, X.H.; Xiong, T. Q.; Xia, Y.Y.; Ning, Y. Two new abietane diterpenoids from the caulis and leaves of Callicarpa kochiana. Fitoterapia, 2012, 83 (1), 1-5.

[59] Tu, W.C.; Wang, S.Y.; Chien, S.C.; Lin, F.M.; Chen, L.R.; Chiu, C.Y.; Hsiao, P.W. Diterpenes from Cryptomeria japonica inhibit androgen receptor transcriptional activity in prostate cancer cells Planta Med., 2007, 73, 1407-1409.

[60] Rodriguez, J. A.; Theoduloz, C.; Yanez, T.; Becerra, J.; SchmedaHirschmann, G. Gastroprotective and ulcer healing effect of ferruginol in mice and rats. Life Sci., 2006, 78, 2503-2509.

[61] Areche, C.; Theoduloz, C.; Yanez, T.; Souza-Brito, A.R.M Barbastefano, V.; de Paula, D.; Ferreira, A.L.; SchmedaHirschmann, G.; Rodriguez, J.A. Gastroprotective activity of ferruginol in mice and rats. J. Pharm. Pharmacol., 2008, 60, 245251.

[62] Pan, X.L.; Tan, N.H.; Zeng, G.Z.; Zhang, Y.M.; Jia, R.R Amentoflavone and its derivatives as novel natural inhibitors of human Cathepsin B. Bioorg. Med. Chem., 2005, 13, 5819-5825.

[63] Zeng, G.Z.; Pana, X.L.; Tana, N.H.; Xiong, J.; Zhang, Y.M. Natural biflavones as novel inhibitors of cathepsin B and K. Eur. J. Med. Chem., 2006, 41, 1247-1252. 